\title{
Psychological Status of Private Commercial Bank Employees in Bangladesh during COVID-19
}

\author{
MD. MIZANUR RAHMAN ${ }^{1 *}$, MD. BASHIR UDDIN ${ }^{2}$, \\ MD. SOLAIMAN CHOWDHURY ${ }^{3}$ and MD. SAIDUR RAHAMAN ${ }^{4}$
}

\begin{abstract}
1'Department of Business Administration, International Standard University, Bangladesh. ${ }^{2}$ Department of Management Studies, Bangabandhu Sheikh Mujibur Rahman Science and Technology University.

${ }^{3}$ Department of Management Studies, Rajshahi University, Bangladesh. ${ }^{4}$ Department of Business Administration, Metropolitan University Sylhet, Bangladesh.
\end{abstract}

\section{ABSTRACT}

On March 8, 2020, the first Covid-19 case was registered in Bangladesh, and the first death occurred on March 18, 2020. Still, the positive corona patients including banking employees are rising around and many negative thoughts are also increasing day by day in mind. These circumstances make the employees worried. Consequently, this paper's fundamental objective is to find out the psychological status of private commercial bank employees during COVID-19. Using a random sampling technique and a questionnaire through "Google Form" the data was gathered from 151 employees. For the completion of the data analysis procedures, the Statistical Package for Social Sciences (SPSS-22 Version) was used. The major findings showed a maximum of $91 \%$ of employees felt nervous when s (he) hears someone died from COVID-19. In addition, $83 \%$ of employees are always fear of COVID- 19 infection, $81 \%$ of employees are fear when they hear someone got tested positive for COVID-19. Besides, $49 \%$ of bank employees cannot concentrate on their regular activities while $40 \%$ of employees are stressed to lose their current job due to COVID-19. The policy-making authorities of private commercial banks in Bangladesh will get an opportunity to know the employees' psychological status during COVID-19. They can also make some necessary measures (based on our recommendations) to overcome these challenges.

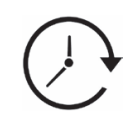

Article History

Received: 01 July 2021

Accepted: 10 August 2021

\section{Keywords}

Bangladesh;

COVID-19;

Employees;

Private Banks;

Psychological Status.

CONTACT Md. Mizanur Rahman 1 mizanmgt@gmail.com 9 Department of Business Administration International Standard University, Bangladesh.

\section{(c) (i)}

(c) 2021 The Author(s). Published by Enviro Research Publishers.

This is an Open Access article licensed under a Creative Commons license: Attribution 4.0 International (CC-BY).

Doi:http://dx.doi.org/10.12944/JBSFM.03.01-02.07 


\section{Introduction}

Even a few days ago, the word Coronavirus (COVID-19) was unfamiliar to the world (Wang, 2020). Everyone is now talking about and concerned about the deadly virus (Rahaman et 2020). The term "corona" is derived from the Latin word "crown," (Shereen et al., 2020). The first new type of coronavirus was discovered in Wuhan, Hubei Province, China, in 2019. (Cascella et al., 2020; Goyal et al., 2020; Nishiura, 2020; Xiang et al., 2020). The first case of Covid-19 was recorded in Bangladesh on March 8, 2020, and the first death occurred on March 18, 2020 (Rahaman et al. 2020) after it originated in China. According to the Department of Health Bulletin, a total of 4 , 07,684 persons have been found infected in the country as of October 30, 2020. Now in Bangladesh, there have been 17465 deaths in the country (bdnewes24.com). This unknown virus has changed the face of the world abruptly. Corona is transforming everything in trade, economics, politics, inter-state relations, sociology, and lifestyle. Many people have voluntarily chosen to be placed under home isolation. Corona has brought stagnation to all socioeconomic areas on the planet. At the same time, it provides opportunities for people to change their life styles in healthy way. The principle of accessing services from a distance of three feet or more, as directed by the World Health Organization and enforced by the government, is being implemented everywhere: in marketplaces, stores, supermarkets, hospitals, autos, offices, courts, and banks. People are gathering together in quest of a livelihood to become acclimated to daily living.

The key driving force of the economy, the banking sector (Rahman et al, 2013, Rahman et al, 2017, Rahman et al, 2018, Rahman et al, 2020), has lost the most. There is a total of 43 PCBs in Bangladesh are in operation right now (Rahman et al, 2021, Rahman et al, 2019,) There is pressure on the banks, on the one hand, to disburse loans, but there is no recovery. As a consequence, the bank's revenue has declined. Moreover, different problems face the country's banking sector, including defaulted loans, liquidity problems, and declining earnings. To overcome from these problems during COVID-19, all bank employees will be paid twice their basic monthly wages for being present at the workplace for 10 days during the government's public holidays to curb the spread of coronavirus (bdnews24.com).
As a special bonus allowance, banks' temporary or contracted officers, those who do not pay basic salaries individually, will receive 65 percent of their gross salary. In this respect, the central bank issued a circular. "Bank employees risk their lives to keep our economy functional, so they need to earn additional payments," said the Executive Director and Spokesperson of the Bangladesh Bank. The special bonus allowance would be provided to staff who have been present at the bank for less than 10 days during the holiday in relation to the number of days they have come to work, the circular says. The monthly unpaid bonus payment for all workers-contractual or permanent, however, will be a minimum of Tk30, 000 and a maximum of Tk1 lakh. However, all office courts across the country have been closed since 26th March 2020, except for emergency services, even, bank transactions are limited. The bank runs transactions from 10 am to 12 noon, and the bank is open until half-past seven in the afternoon. In this scenario, Bangladesh Bank released a circular for the convenience of the customers. The new time, from 10 am to $1 \mathrm{pm}$; the bank agreed to raise the transaction time by one hour. The bank is open until $3 \mathrm{pm}$. The government has declared a 10-day general holiday in the country to curb the coronavirus outbreak but has been instructed to keep banking services limited. But many banks do not have personal protective equipment (PPE) to prevent the virus from protecting their officers and staff, leading to security concerns. Their families are also concerned about their loved ones' wellbeing. The main reason is the sudden change in lifestyle due to the lockdown. Other reasons are anxiety (Ayittey et al., 2020), uncertainty about the future, loss of savings, busy employees being lazy, fear of losing their relations (Moreno et al., 2019) etc. Experts claim that the risk of mental health is higher at this time as hundreds of millions of people around the world are confined at home and socially isolated due to the coronavirus (Dong et al., 2020). These mental problems can lead to loss of physical and mental health as well as an increased tendency to commit crimes or even suicidal tendencies. Previous many studies have reported the coping strategies by which an individual can help out from the psychological problems, but it has two styles, positive and negative strategies (Xie et al., 1998). Multiple studies have shown that there is a positive correlation between negative coping strategies with the psychological problems, such as depression 
(Shah et al., 2020; Guardino et al., 2014). These are also the root cause of the psychological disorder, anxiety and stress (Mahmoud, et al, 2012) are responsible during COVID-19.

Although many families struggle to deal with the coronavirus outbreak, many private banks in Bangladesh have started cutting their salaries for officers and employees. Banks claim that, because of the pressure of defaulting loans, the liquidity crisis, and the market downturn, they are already on the brink of a coronavirus outbreak and that they have no choice but to cut costs. As the income of every public, private, and international bank has fallen by about 7 percent, the only way for banks to minimize expenditure is now. Therefore, instead of retrenching workers, some banks have decided to cut their salaries to reduce costs. The decision is expected to take effect from July 2020 (Hasan, et al., 2020, Yasmin et al., 2021). Although those banks' employees are furious at such a sudden decision, they will not protest against holding their jobs. A 13-point recommendation was given by the Bangladesh Association of Banks (BAB), which includes a reduction in the salaries of its member bank employees for the next 18 months. The BAB, a forum of directors of the country's private commercial banks (PCBs), sent a letter to its president to overcome the economic recession triggered by the Covid-19 outbreak. The letter also instructed members not to limit their workers' employment from July 12020 to December 31 2021. The recommendations of the $\mathrm{BAB}$ include a 15 percent reduction in salary only for workers who receive more than Tk 40,000 as gross salary per month, suspension of the opening of new branches and the acquisition of fixed assets, stopping ads in print and electronic media and corporate social responsibility spending, decreasing local and international training and employee tour ( Hasan et al., 2020, Yasmin et al., 2021; TFE, 2020) . In addition, According to CBN (2020), many bank employees had tested COVID-19 positive. The Bangladesh Daily Star ((June 4) reported that 50 central bank officials had tested positive for Covid-19, and all of them are in Anwer Khan Memorial Hospital in Dhaka. That newspaper also reported that that number must be even higher if the other hospitals have also been checked. (CBN, 2020). The above circumstances make the bank employees anxious. Consequently, the fundamental objective of this paper is to find out the psychological status of private commercial bank employees during COVID-19.

\section{Methodology \\ Procedures of Study and Subject Selection}

We distributed our well-structured questionnaire to bank employees employed in Bangladesh's private commercial banks at random. We only select the private commercial bank employees as their working natures, benefits; motivational factors are different from the public bank employees. However, physically, it was impossible to go to banks to collect the data due to the COVID-19 situation. As a result, the researchers created a questionnaire in "Google Form" with a consent sheet and distributed it through various electronic channels such as WhatsApp, Messenger, and Facebook groups. The questionnaire also stated that participation is fully voluntary and anonymous. However, one week was given to complete the questionnaire. Finally, 156 bank employees completed the survey, but 151 bank employees were the final sample in this study due to missing information.

\section{Pattern of the Questionnaire}

We divided our questionnaire into two sections. We placed some demographic relevant questions in the first segment of the questionnaire to determine our respondents' demographic details. In the second part, psychological status-related items were selected from different published articles about psychological status. "5 Likert Type Scale" where 1= Strongly Disagree and 5=Strongly Agree has been adopted to get the respondents opinion. Statistical Package for the Social Sciences (SPSS-22 Version) was applied to complete the data analysis procedures. In the last part of the questionnaire, respondents were asked to put some recommendations to improve the psychological status during COVID-19. However, the items in relation to psychological status are given the following Table.

\section{Plans for Analysis}

In the first stage of data analysis, we have checked the data's accuracy, including reliability and normality. The reliability value of psychological status-related items were. 811, which confirms a good consistency of data. In the second part of the data analysis, the demographic and descriptive analyses have been done. 
RAHMAN et al., Journal of Business Strategy Finance and Management,

$$
\text { Vol. 03(1-2) 66-73 (2021) }
$$

Table 1: Scales of measures with reliability during pilot test and for actual data

\begin{tabular}{lll}
\hline & List of the Items & Sources \\
\hline $\begin{array}{l}\text { Psychological } \\
\text { status }\end{array}$ & Always keep me stress to lose the current job. & Brooks, et al. (2020). \\
& I am always depressed, and I am feeling anxious \\
about the current COVID-19 situation. & (Malinauskiené \\
et al., 2016; & \\
& $\begin{array}{l}\text { I cannot concentrate on my regular banking activities } \\
\text { due to current COVID-19 conditions. }\end{array}$ & \\
& When I hear someone got tested positive for COVID-19, I feel fear. & \\
& $\begin{array}{l}\text { When I get information about COVID-19 from online } \\
\text { sources, I feel frustrated and bored. }\end{array}$ \\
& Always keep me in fear of infection. \\
& $\begin{array}{l}\text { I am always feeling nervous when I hear someone } \\
\text { died from COVID-19. }\end{array}$
\end{tabular}

Table 2: Demographic Information

\begin{tabular}{lcc}
\hline & Frequency & Percentage \\
\hline Gender & & \\
Male & 124 & 82 \\
Female & 27 & 18 \\
Age (Years) & & \\
$23-27$ & 25 & 17 \\
$28-35$ & 85 & 56 \\
36-above & 41 & 27 \\
Marital Status & & \\
Married & 123 & 81 \\
Unmarried & 28 & 19 \\
Level of Education & & \\
Bachelor & 11 & 7 \\
Masters & 129 & 86 \\
Others & 11 & 7 \\
\hline
\end{tabular}

Source: Online survey, 2020

\section{Results and Discussions \\ Demographic Results}

Demographic statistics were conducted in order to learn about the general socio-demographic characteristics of private commercial banks in Bangladesh, such as their gender, age, marital status, and level of education. The following Table shows the total demographic statistics.
Table 2 shows that 83 percent of workers are male, while 17 percent are female, and that 81 percent of respondents are married, while 19 percent are single. The majority of workers (56 percent) are between the ages of 28 and 35. According to the standard of qualifications, 86 percent of bank workers have a master's degree or higher.

\section{Percentile Calculation}

To find out the psychological status of private commercial bank employees in Bangladesh, we have done the percentile calculation. To calculate the total agreement in relation to our psychological statement, we combined "Agree and Strongly Agree." In Table 3, we combined (column 4 and column 5). Based on the percentile values related to the psychological status, a maximum of $91 \%$ of employees feel nervous when $\mathrm{s}(\mathrm{he})$ hears someone die from COVID-19. In addition, $83 \%$ of employees are always feared of COVID-19 infection; $81 \%$ of employees are fear when they hear someone got tested positive for COVID-19. Besides, $49 \%$ of bank employees cannot concentrate on their regular activities, while $40 \%$ of employees are stressed to lose their current job due to COVID-19. 
RAHMAN et al., Journal of Business Strategy Finance and Management,

Vol. 03(1-2) 66-73 (2021)

Table 3: Respondents' opinion (percentage)

\begin{tabular}{|c|c|c|c|c|c|c|c|}
\hline & List of the Items & $\begin{array}{l}\text { SD } \\
(\%) \\
{[1]}\end{array}$ & $\begin{array}{l}D \\
(\%) \\
{[2]}\end{array}$ & $\begin{array}{l}\mathrm{N} \\
(\%) \\
{[3]}\end{array}$ & $\begin{array}{l}A \\
(\%) \\
{[4]}\end{array}$ & $\begin{array}{l}\text { SA } \\
(\%) \\
{[5]}\end{array}$ & $\begin{array}{l}\text { Total } \\
\text { Agreement } \\
\%[4+5]\end{array}$ \\
\hline \multirow[t]{7}{*}{$\begin{array}{l}\text { Psychological } \\
\text { status }\end{array}$} & $\begin{array}{l}\text { Always keep me stress to lose the } \\
\text { current job. }\end{array}$ & 3 & 26 & 33 & 23 & 17 & $40 \%$ \\
\hline & $\begin{array}{l}\text { I am always depressed, and I am } \\
\text { feeling anxious about the current } \\
\text { COVID- } 19 \text { situation. }\end{array}$ & 3 & 6 & 13 & 61 & 17 & $78 \%$ \\
\hline & $\begin{array}{l}\text { I cannot concentrate on my regular } \\
\text { banking activities due to the current } \\
\text { COVID-19 conditions. }\end{array}$ & 6 & 34 & 11 & 36 & 13 & $49 \%$ \\
\hline & $\begin{array}{l}\text { When I hear someone got tested } \\
\text { positive for COVID-19, I feel fear. }\end{array}$ & 00 & 10 & 9 & 45 & 36 & $81 \%$ \\
\hline & $\begin{array}{l}\text { When I get information about } \\
\text { COVID-19 from online sources, } \\
\text { I feel frustrated and bored. }\end{array}$ & 2 & 19 & 15 & 38 & 26 & $64 \%$ \\
\hline & Always keep me in fear of infection. & 5 & 6 & 6 & 57 & 26 & $83 \%$ \\
\hline & $\begin{array}{l}\text { I am always feeling nervous when I } \\
\text { hear someone died from COVID-19. }\end{array}$ & 00 & 00 & 9 & 53 & 38 & $91 \%$ \\
\hline
\end{tabular}

Here, $S D=$ Strongly Disagree, $D=$ Disagree, $N=$ Neutral, $A=$ Agree, $S A=$ Strongly Agree

\section{Discussions}

According to the (IEDCR, 2020), the first three coronavirus-infected patients were discovered in Bangladesh on March 7, 2020. Overall, people, including bank employees, are experiencing psychological difficulties as a result of receiving updated information about COVID-19 through television, newspapers, and other forms of social media. Now, with a view to sorting out the psychological status of the private commercial banks in Bangladesh, we asked 7 important questions to the private commercial bank employees in Bangladesh. Based on their opinions, maximum $91 \%$ employees fell nervous when $\mathrm{s}(\mathrm{he})$ hears someone died from COVID-19. In addition, $83 \%$ employees are always feared of COVID-19 infection, $81 \%$ employees are fear when they hear someone got tested positive for COVID-19. Besides, $49 \%$ bank employees cannot concentrate on their regular activities while $40 \%$ employees are stressed to lose their current job due to COVID-19. Frustration, anxiety, boredom, and fear are also challenges for Bangladesh during the COVID-19 scenario, as the respondents' response rate is over $50 \%$. The finding and another study is also correlated where in the time of SARS- 25 people of 1078 were in-home quarantine and reported that $230(20 \%)$ of them were has difficulties with anger, sadness and nervousness were observed within $18 \%$ and guilty were within $10 \%$ (101) of people. According to a survey, respondents whose main source of income was from the horse-related industry saw their income drop by half after being quarantined for equine influenza, with the tension from the quarantine accounting for the difference (Taylor et. al, 2008). Besides, participants in the previous eight studies have expressed concerns not only for their own safety but also for the safety of others (Chen et al., 2020; Wang et al.,2020; Wester, 2019; Desclaux, 2017) and fears are particularly high for family members who are not subjected to the quarantine. People became worried if they had any physical symptoms after the infection and if it continues and found any mental disorders after months while.

\section{Strengths and Contributions of this Paper}

The present research is remarkable. To date (06-182021), according to research information, no such research can be found relevant to the psychological status of private commercial bank employees in Bangladesh. Policy-making authorities will highly appreciate our research findings, such as private 
Vol. 03(1-2) 66-73 (2021)

commercial banks, the central bank, the Ministry of Health, and the IEDCR. In order to resolve the difficulties and deal mentally with COVID-19 or such a pandemic in the immediate future, authorities should take certain precautionary steps based on the research guidelines.

\section{Conclusion and Recommendations}

In Bangladesh, all private and public organizations have been closed on 26th March 2020, except for some emergency services. Beginning of the lockdown, all of the bank transactions were also banned; after a while, banks were opened with the very limited transaction and time. The banking transaction lasts from 10 am to 12 noon, and the banks are opened and perform their internal activities until half-past seven in the evening. Later on, Bangladesh Bank fixes a new time frame extending one more hour (10 am to $1 \mathrm{pm}$ ) for the transaction and close at $3 \mathrm{pm}$ by releasing a circular. Surprisingly, most of the banks do not have personal security equipment (PPE) to prevent the virus from protecting their officers and staff, leading to security concerns. Experts say that at this time, the risk of mental well-being is higher as hundreds of millions of people around the world are confined due to the coronavirus at home and socially isolated (Dong et al., 2020). This situation makes the employees mentally disorder. Such mental disorders can lead to physical and psychological health failure and an increased propensity to commit crimes or even suicide. In the last part of the questionnaire, we requested the respondents (bank employees) to share their recommendations to improve the private commercial bank employees' psychological status in Bangladesh. However, based on their opinions, we have gathered the following recommendations.

- Banking authorities should ensure not to lay off any employee instead of advised them; if an employee is ill or has the corona symptoms, it is better not to visit his office. Besides, he or she can inform the issue to the concerned bank authorities.

- Banking authorities should ensure medical expenses along with medical insurance.

- As the enemy is invisible, so we should consider more concern about the virus. Employees should not be depressed and anxious, instead of taking necessary pre-cautious (Wearing a face mask, face shield, PPE, and using sanitizer); the authorities should give every worker essential protective clothing.

- During the pandemic and unfixed lockdown, the regular life schedule has been vastly disrupted. At this time, concentrating on the daily official activities is challenging. Bank authorities should arrange some motivational programs and provide some incentives to keep them engaged in activities.

- Banking authorities can arrange some online campaigns to remove the fear and stigma of covid-19 from the employees' minds and learn coping mechanisms properly.

- $\quad$ Each of the employees should develop positive psychology towards the covid-19. The usage of online banking should be encouraged more.

- Finally, employees are requested to follow the rules and regulations provided by the Bangladesh government.

\section{Limitations and Areas for Future Research}

In this research, many important psychological issues were ignored. As a result, it is recommended that psychological problems be included in any potential study. Another significant drawback of this paper is its limited use. We only looked at the views of private commercial bank workers, which might differ from those of other employees. Thus, it is suggested to make a comparison between the employees of public and private commercial banks in Bangladesh concerning their psychological status.

\section{Acknowledgment}

We the authors are grateful to the respondents for their co-operations to complete this research. Besides, we are also grateful to the reviewers.

\section{Funding}

The authors did not receive any fund for this research project.

\section{Conflict of Interest}

The authors declare that they have no competing interests. 


\section{References}

1. Ayittey, F. K., Ayittey, M. K., Chiwero, N. B., Kamasah, J. S. and Dzuvor, C., (2020). Economic impacts of Wuhan 2019-nCoV on China and the world. Journal of Medical Virology, 92(5), 473-475.

2. bdnews24.com. (2020). Bangladesh Bank announces "incentives" for bankers working during viruslockdown.'https://bdnews24. com/business/2020/04/13/bangladeshbank-announces-incentives-for-bankersworkingduring- virus-lockdown. Accessed 06 July 2020.

3. Brooks SK, Webster RK, Smith, LE, Woodland L, Wessely S, Greenberg N, and Rubin GJ. (2020) The psychological impact of quarantine and how to reduce it: a rapid review of the evidence. The Lancet 395(1):912-920.

4. Cascella, M., Rajnik, M., Cuomo, A., Dulebohn, S. C. and Di Napoli, R., (2020). Features, evaluation and treatment coronavirus (COVID-19). In Statpearls [internet]. StatPearls Publishing.

5. Central Banking Newsdesk (CBN) 04 Jun 2020. https://www.centralbanking.com/central-banks/ governance/7554046/at-least-50-bangladeshbank-officials-test-positive-for-covid-19

6. Chen, Q., Liang, M., Li, Y., Guo, J., Fei, D., Wang, L., \& Zhang, Z. (2020). Mental health care for medical staff in China during the COVID-19 outbreak. The Lancet Psychiatry, 7(4), e15-e16. 10.1016/S2215-0366(20)30078-X,

7. Corona Tracker (2020), https://www. coronatracker.com/country/bangladesh/

8. Desclaux, A., Badji, D., Ndione, A. G. and Sow, K., (2017). Accepted monitoring or endured quarantine? Ebola contacts' perceptions of Senegal. Social science and medicine, 178, 38-45.

9. Dong, L. and Bouey., (2020). Early ReleasePublic Mental Health Crisis during COVID-19 Pandemic, China.

10. Goyal, P., Choi, J. J., Pinheiro, L. C., Schenck, E. J., Chen, R., Jabri, A. and Hoffman, K. L., (2020). Clinical characteristics of Covid-19 in New York City. New England Journal of Medicine.

11. Guardino, C. M. and Dunkel Schetter, C., (2014).
Coping during pregnancy: a systematic review and recommendations. Health psychology review, 8(1), 70-94.

12. Hasan, M. (2020). Bangladesh Association of Banks recommends up to $15 \%$ cut in salaries. Dhaka tribune.Fbclid=IwAR0JWhOUoSuQljgk Q5IsFMj3BFREEaFx4uSpZzojdLTDIw7IIEDiy NA_jwY.Accessed 07 July 2020. https://www. dhakatribune.com/business/banks/2020/06/14/ bab-recommends-up-to-15-cut-insalaries?

13. Institute of Epidemiology, Disease Control and Research (IEDCR), (2020). corona.gov.bd. (retrieved 27 March 2020).

14. Mahmoud, J. S. R., Staten, R. T., Hall, L. A. and Lennie, T. A., (2012). The relationship among young adult college students' depression, anxiety, stress, demographics, life satisfaction, and coping styles. Issues in mental health nursing, 33(3), 149-156.

15. Malinauskienè, V. and Bernotaitè, L., (2016). The Impact of Event Scale-Revised: psychometric properties of the Lithuanian version in a sample of employees exposed to workplace bullying. Acta medica Lituanica, 23(3), 185.

16. Nishiura, H., Jung, S. M., Linton, N. M., Kinoshita, R., Yang, Y., Hayashi, K.and Akhmetzhanov, A. R.,( 2020). The extent of transmission of novel coronavirus in Wuhan, China, 2020.

17. Rahman, M. M., Abdul, M., Ali, N. A., Uddin, M. J., \& Rahman, M. S. (2017), "Employees' Retention Strategy on Quality of Work Life (QWL) Dimensions of Private Commercial Banks in Bangladesh", Pertanika Journal of Social Sciences \& Humanities, 25 (2), 647-662.

18. Rahman, M. M., Abdul, M., Mansor, Z. D., Ali, N. A., Adedeji, S. B., Uddin, M. J., Ogiri, I., \& Rahaman, M. S. (2018), "Effect of work-family conflict on job satisfaction of academicians of private universities in Bangladesh: A structural equation modeling approach", Journal of Advanced Research in Social and Behavioral Sciences, 10 (1), 1-8.

19. Rahman, M. M., Uddin, M. J., \& Rahaman, S. (2019), "Work-family, family-work conflict and subjective well-being of commercial bank employees in Bangladesh: The moderating effects of organisational supports", Advances 
in Management and Applied Economics, 9(6), 77-96.

20. Rahman, M. M., Ali, N. A., Jantan, A. H., Dato'Mansor, Z., \& Rahaman, M. S. (2020), "Work to family, family to work conflicts and work family balance as predictors of job satisfaction of Malaysian academic community", Journal of Enterprising Communities: People and Places in the Global Economy, 14(4), 621-642.

21. Rahman, M. M., \& Ali, N. A. (2021), "Does workfamily balance mediate the relationship between work-family conflicts and job satisfaction of academicians?", Journal of Community Psychology, 49 (2), 361-374.

22. Rahman, M. M., \& Iqbal, F. (2013). A comprehensive relationship between job satisfaction and turnover intention of private commercial bank employees' in Bangladesh. International Journal of Science and Research, 2(6), 17-23.

23. Rahaman, M. S., Rahman, M. M., \& Moral, I. H. (2020). Informative knowledge and challenges of home quarantine during COVID-19 in Bangladesh. International Journal of Technology Transfer and Commercialisation, 17(4), 354-367.

24. Shah, K., Kamrai, D., Mekala, H., Mann, B., Desai, K. \& Patel, R. S., (2020). Focus on mental health during the coronavirus (COVID-19) pandemic: applying learnings from the past outbreaks. Cureus, 12(3), e7405.
25. The financial express June 15, 2020 , https://thefinancialexpress.com.bd/ economy/covid-19-pandemic-bab-issues13-point-recommendation-for-memberbanks-1592211583

26. Wang, C., Horby, P. W., Hayden, F. G. \& Gao, G. F., (2020). A novel coronavirus outbreak of global health concern. The Lancet, 395(10223), 470-473.

27. Wester, M. \& Giesecke, J., (2019). Ebola and healthcare worker stigma. Scandinavian journal of public health, 47(2), 99-104.

28. Xiang, Y. T., Yang, Y., Li, W., Zhang, L., Zhang, Q., Cheung, T. \& Ng, C. H., (2020). Timely mental health care for the 2019 novel coronavirus outbreak is urgently needed. The Lancet Psychiatry, 7(3), 228-229.

29. Yasmin, S., Alam, M. K., Ali, F. B., Banik, R., \& Salma, N. (2021). Psychological Impact of COVID-19 Among People from the Banking Sector in Bangladesh: a Cross-Sectional Study. International Journal of Mental Health and Addiction, 1-15.

30. Xie, Y., (1998). Reliability and validity of the simplified Coping Style Questionnaire. Chinese Journal of Clinical Psychology.

31. Xu, J. \& He, Y., (2012). Psychological health and coping strategy among survivors in the year following the 2008 Wenchuan earthquake. Psychiatry and Clinical Neurosciences, 66(3), 210-219 